\title{
Stress Degradation Studies of Macrolide Antibiotics "Roxithromycin, Tilmicosin and Tylosin" by Using HPLC
}

Bediha Akmese

Hitit University, Department of Chemistry, Corum, Turkey

\section{ABS T R ACT}

tress degradation studies control the behavior and impurities of drugs under various $\checkmark$ stress conditions. The present research is related to all degradation studies including acidic, alkaline, thermal and photo stability on the drug substance according to International Conference on Harmonization (ICH) guidelines. In this study, the degradation profiles of macrolide antibiotics "roxithromycin (ROX), tilmicosin (TIL) and tylosin (TYL)" under varied stress conditions were investigated. The behavior of these drugs under hydrolytic, oxidative, thermal and photolytic conditions were determined by high performance liquid chromatography (HPLC).

Keywords:

Degradation; Macrolide; Roxithromycin; Tilmicosin; Tylosin.

\section{INTRODUCTION}

A ntibiotics are natural or synthetic chemical substances produced by microorganisms to kill or stop the growth of another microorganisms [1]. They are used in treatment of diseases in humans. They are used in animals for the treatment of diseases and as feed-additives for rapid growth of animals [2]. ROX is 14-membered ring macrolide antibiotic, which is effective against certain respiratory tract, urinary and soft tissue infections [3]. It is a semi-synthetic, derived from erythromycin. TIL is a semi-synthetic, derived from desmycosin, commonly used in veterinary treatment for bacterial respiratory diseases. It is 16-membered ring macrolide antibiotic [4-6]. TYL is a complex of 16-member macrolides obtained from the fermentation of Streptomyces fradie. It is generally used as a growth promotant for food-producing animals (Fig. 1). It is effective against Gram-positive bacteria [7].

Stability is a critical parameter affecting the purity, potential and safety of the drugs, so stability studies are one of important parameters of the quality control of drugs $[8,9]$. Stability studies are important to indicate the expiration date, appropriate storage and transport conditions of drugs. In addition, stress degradation studies are important to simulate the unintended exposure of drugs to undesirable conditions during production, storage, usage and administration.

The present manuscript describes the stress degradation studies of ROX, TIL and TYL under various conditions prescribed by $\mathrm{ICH}$. The ICH guidelines are important not only to ensure the stability of drug molecules, but also for the identification and structure of degradation products and for the selection of possible stabilizers to prevent from degradation [10].

In this study, degradation of ROX, TIL and TYL under acidic and alkaline, thermal, oxidation and ultraviolet (UV) light conditions were investigated. This study will be valuable for ensuring the chemical stability

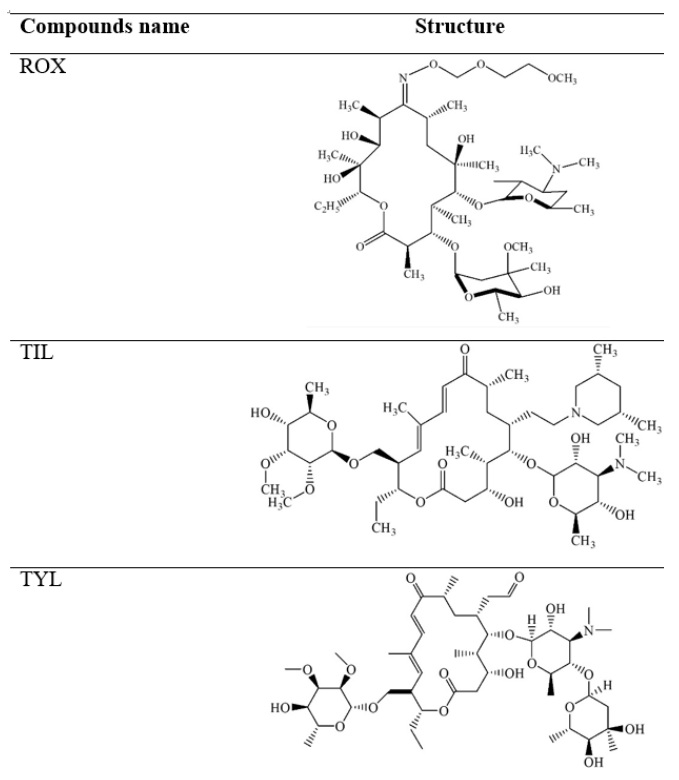

Figure 1. Molecular forms of compounds studied. 
of these substances and for developing appropriate formulations and screening for appropriate storage conditions. To our knowledge, only one study in the literature demonstrated the stress degradation conditions for ROX. Degradation products were determined and kinetic studies were conducted in the study however degradation rates following stress conditions were not calculated. So, our study was the first study that calculated the degradation rates for ROX after treatment with stress parameters [11]. No reports have been found in the literature about the identification of stability and degradation products of TIL and TYL.

\section{MATERIAL AND METHODS}

\section{Chemical and Reagents}

ROX, TIL, TYL and Methanol (HPLC- grade) were purchased from Sigma-Aldrich. Acetonitrile (HPLC-grade) and sodium hydroxide were purchased from Merck. Ortho-phosphoric acid (min. 85\%), hydrochloric acid (37\%, d: $1.19 \mathrm{~g} \mathrm{~cm}^{-3}$ ) and hydrogen peroxide (35\%, d: $1.13 \mathrm{~g} \mathrm{~cm}^{-3}$ ) were purchased from Riedel de Haen.

\section{Apparatus and Chromatographic Procedure}

The chromatographic apparatus consisted of a model LC-20 AD quaternary pump, a model DGU 20A vacuum degasser and a model SPD-M 20A DAD detector, a model CTO-20AC column oven, all from Shimadzu (Kyoto, Japan). The separation was performed on Intertsil ${ }^{\circ}$ ODS$4 \mathrm{~V}(5 \mu \mathrm{m}, 4.60 \times 250 \mathrm{~mm})$ column. The wavelengths were set at $210 \mathrm{~nm}$ for ROX, $288 \mathrm{~nm}$ for TIL and TYL. Mettler Toledo (Greifensee, Switzerland) was used for $\mathrm{pH}$ measurements. Ultra-pure water device, Human Corp. Zeneer Power I brand was used. The mobile phase was a mixture of 40:60\% (v/v) acetonitrile: water containing $20 \mathrm{mM}$ ortho-phosphoric acid and $\mathrm{pH}$ was adjusted to 2.8 with 1.0 $\mathrm{M} \mathrm{NaOH}$. Isocratic flow rate is $1.0 \mathrm{~mL} / \mathrm{min}$. The column temperature is $35^{\circ} \mathrm{C}$. [12-14]. Injection volume was $20 \mu \mathrm{L}$. The mobile phase was prepared daily and degassed with ultrasonicator before use.

\section{Preparation of Stock Solutions}

Stock solutions (200 ppm) were prepared by dissolving the studied drugs in methanol. 2.0 $\mathrm{M} \mathrm{HCl}, 2.0 \mathrm{M} \mathrm{NaOH}$, $30 \% \mathrm{H}_{2} \mathrm{O}_{2}$ and $6 \% \mathrm{H}_{2} \mathrm{O}_{2}$ solution were dissolved in purified water. All stock solutions were stored in the dark and at $+4{ }^{\circ} \mathrm{C}$.

\section{Stress-Degradation Studies}

Stress degradation studies were attempted to stress conditions of acidic, alkaline, oxidation, heat in oven $\left(\right.$ at $\left.100^{\circ} \mathrm{C}\right)$ and UV light to detect the degradation products of ROX, TIL and TYL under chromatographic conditions previously described [15]. For acidic degradation, to a $5.0 \mathrm{~mL}$ stock solutions of each drug was added an appropriate volume of $2.0 \mathrm{M} \mathrm{HCl}$ and the mixture was diluted to $10 \mathrm{~mL}$ with water to achieve a molarity of $0.1 \mathrm{M}$ and $1.0 \mathrm{M} \mathrm{HCl}$, respectively. The mixtures were kept at room temperature for $24 \mathrm{~h}$. Alkaline degradation studies were carried out in a similar manner to that of acidic degradation with molarities of $0.1 \mathrm{M}$ and $1 \mathrm{M} \mathrm{NaOH}$. The mixtures were kept at room temperature for $24 \mathrm{~h}$. For oxidative stress, to a $5.0 \mathrm{~mL}$ stock solutions of each drug $5.0 \mathrm{~mL}$ of $6 \%(\mathrm{v} / \mathrm{v})$ $\mathrm{H}_{2} \mathrm{O}_{2}$ and $30 \%(v / v) \mathrm{H}_{2} \mathrm{O}_{2}$ were separately added to reach final concentrations of $3 \%$ and $15 \%(\mathrm{v} / \mathrm{v}) \mathrm{H}_{2} \mathrm{O}_{2}$, respectively. The mixtures were kept at room temperature for 24 h. These experiments also were conducted at $75^{\circ} \mathrm{C}$ for 30 min while keeping all other conditions constant.

The studied drugs were exposed at $100^{\circ} \mathrm{C}$ for $6 \mathrm{~h}$ and $24 \mathrm{~h}$ to determine whether the drugs were degraded by heat. They were dissolved and diluted with methanol to achieve final concentrations of $100 \mathrm{ppm}$. For photolytic stress, drug samples, in solid state, were irradiated with UV radiation having peak intensities at 254 and $360 \mathrm{~nm}$ for 6 and $24 \mathrm{~h}$. They were dissolved and diluted with methanol to achieve final concentrations of $100 \mathrm{ppm}$.

\section{RESULTS AND DISCUSSION}

Stress degradation studies are critical parameters that help to determine the stability of the drug substance, the ways of degradation and the possible degradation products. The rates of degradation of ROX, TIL and TYL under different degradation conditions were calculated (Table 1). Fig. 2-4 represented the chromatograms for degradation of ROX, TIL and TYL, respectively, under different stress conditions.

ROX was completely degraded under alkaline conditions (1.0 M NaOH solution) at $75{ }^{\circ} \mathrm{C}$ indicating that $\mathrm{ROX}$ has much better stability under alkali conditions than acidic ones at room temprerature. It was found that ROX was sensitive to both concentrations of $\mathrm{H}_{2} \mathrm{O}_{2}$ at $75{ }^{\circ} \mathrm{C}$ temperature. The drug was highly stable to thermal and photolytic conditions. It was observed that TIL was resistant to acidic conditions and oxidation. TIL was partially degraded in 1.0 $\mathrm{M} \mathrm{NaOH}$ solution at $75{ }^{\circ} \mathrm{C}$ indicating that degradation under basic conditions was found to be concentration and temperature dependent. It was also partially degraded under thermal and photolytic conditions. TYL was found to be sensitive to acidic, basic and oxidative conditions and almost all drug were degraded. It was partially degraded under thermal and photolytic conditions. 
Table 1. The rates of degradation calculated for ROX, TIL and TYL.

\begin{tabular}{|c|c|c|c|c|}
\hline Degradation Conditions & & ROX\% & TIL\% & $\%$ TYL \\
\hline \multirow[t]{4}{*}{ Acidic conditions } & $0.1 \mathrm{M} \mathrm{HCl}$ & - & - & 92.31 \\
\hline & $1.0 \mathrm{M} \mathrm{HCl}$ & 100 & 6.78 & 97.67 \\
\hline & $0.1 \mathrm{M} \mathrm{HCl}$ at $75^{\circ} \mathrm{C}$ & 10.27 & 11.23 & 96.28 \\
\hline & $1.0 \mathrm{M} \mathrm{HCl}$ at $75^{\circ} \mathrm{C}$ & 100 & 11.66 & 98.49 \\
\hline \multirow[t]{4}{*}{ Alkaline conditions } & $0.1 \mathrm{M} \mathrm{NaOH}$ & - & - & 99.23 \\
\hline & $1.0 \mathrm{M} \mathrm{NaOH}$ & 37.93 & 5.59 & 99.51 \\
\hline & $0.1 \mathrm{M} \mathrm{NaOH}$ at $75^{\circ} \mathrm{C}$ & - & 9.89 & 99.69 \\
\hline & $1.0 \mathrm{M} \mathrm{NaOH}$ at $75^{\circ} \mathrm{C}$ & 100 & 68.02 & 99.76 \\
\hline \multirow[t]{4}{*}{ Oxidative Conditions } & $3 \% \mathrm{H}_{2} \mathrm{O}_{2}$ & 11.08 & 16.72 & 87.98 \\
\hline & $15 \% \mathrm{H}_{2} \mathrm{O}_{2}$ & 12.71 & 21.43 & 97.29 \\
\hline & $3 \% \mathrm{H}_{2} \mathrm{O}_{2}$ at $75^{\circ} \mathrm{C}$ & 100 & 21.21 & 89.23 \\
\hline & $15 \% \mathrm{H}_{2} \mathrm{O}_{2}$ at $75^{\circ} \mathrm{C}$ & 100 & 22.13 & 99.32 \\
\hline \multirow[t]{2}{*}{ Thermal Conditions } & $6 \mathrm{~h}$ at $100^{\circ} \mathrm{C}$ & - & 23.65 & 31.31 \\
\hline & $24 \mathrm{~h}$ at $100^{\circ} \mathrm{C}$ & - & 33.21 & 59.39 \\
\hline \multirow[t]{4}{*}{ Photolytic Conditions } & $254 \mathrm{~nm}$ for $6 \mathrm{~h}$ & 10.88 & - & 1.81 \\
\hline & $254 \mathrm{~nm}$ for $24 \mathrm{~h}$ & 12.91 & 13.99 & 76.09 \\
\hline & $360 \mathrm{~nm}$ for $6 \mathrm{~h}$ & 0.13 & 19.76 & 68.76 \\
\hline & $360 \mathrm{~nm}$ for $24 \mathrm{~h}$ & 2.12 & 39.81 & 69.64 \\
\hline
\end{tabular}
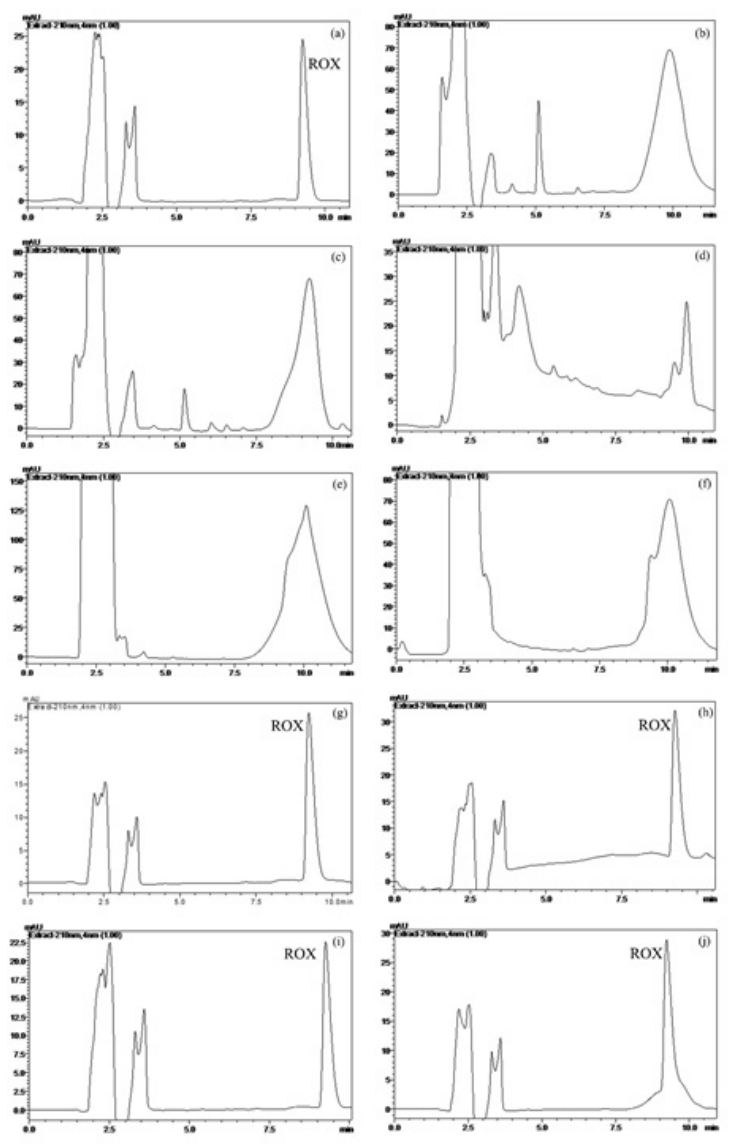

Figure 2. Chromatograms of (a):100 ppm ROX and degradation of ROX under (b): $1.0 \mathrm{M} \mathrm{HCl},(\mathrm{c}): 1.0 \mathrm{M} \mathrm{HCl}$ at $75^{\circ} \mathrm{C}$, (d): $1.0 \mathrm{M} \mathrm{NaOH}$ at $75^{\circ} \mathrm{C}$ (e): $3 \% \mathrm{H}_{2} \mathrm{O}_{2}$ at $75^{\circ} \mathrm{C}$, (f): $15 \% \mathrm{H}_{2} \mathrm{O}_{2}$ at $75{ }^{\circ} \mathrm{C}$, (g): $6 \mathrm{~h}$ at $1000 \mathrm{C},(\mathrm{h}): 24 \mathrm{~h}$ at $100{ }^{\circ} \mathrm{C}$, (i): $254 \mathrm{~nm}$ for $24 \mathrm{~h},(\mathrm{j}): 360 \mathrm{~nm}$ for $24 \mathrm{~h}$
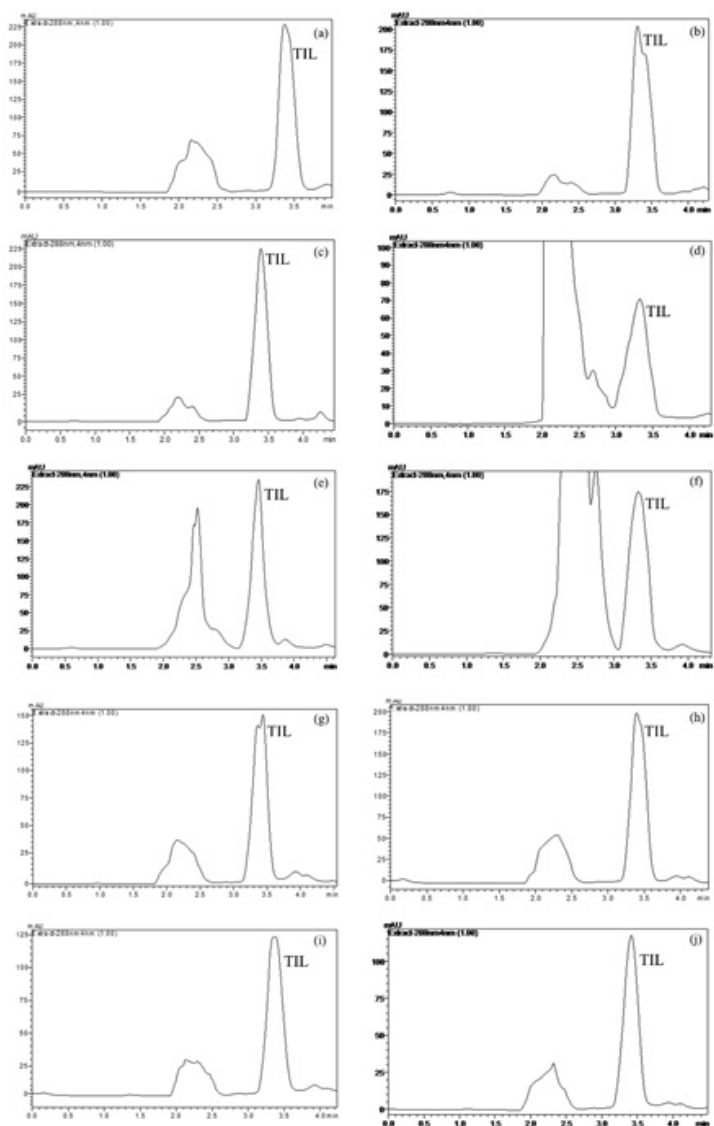

Figure 3. Chromatograms of (a):100 ppm TIL and degradation of TIL under (b): $1.0 \mathrm{M} \mathrm{HCl}$, (c): $1.0 \mathrm{M} \mathrm{HCl}$ at $75^{\circ} \mathrm{C}$, (d): $1.0 \mathrm{M} \mathrm{NaOH}$ at $75{ }^{\circ} \mathrm{C}$, (e): $3 \% \mathrm{H}_{2} \mathrm{O}_{2}$ at $75{ }^{\circ} \mathrm{C}$, (f): $15 \% \mathrm{H}_{2} \mathrm{O}_{2}$ at $75{ }^{\circ} \mathrm{C}$, (g): $6 \mathrm{~h}$ at $1000 \mathrm{C},(\mathrm{h}): 24 \mathrm{~h}$ at $100{ }^{\circ} \mathrm{C}$, (i): $254 \mathrm{~nm}$ for $24 \mathrm{~h}$, (j): $360 \mathrm{~nm}$ for $24 \mathrm{~h}$. 

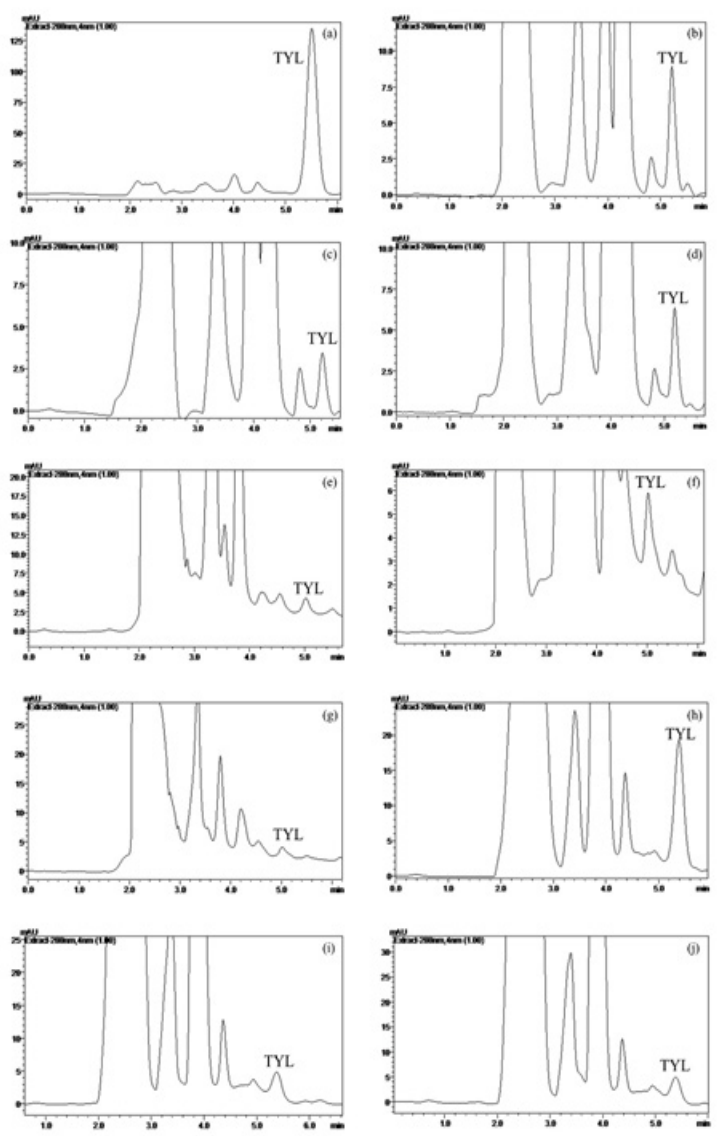

Figure 4. Chromatograms of (a):100 ppm TYL and degradation of TYL under (b): $1.0 \mathrm{M} \mathrm{HCl}$, (c): $1.0 \mathrm{M} \mathrm{HCl}$ at $75^{\circ} \mathrm{C}$, (d): $1.0 \mathrm{M} \mathrm{NaOH}$ at $75^{\circ} \mathrm{C}$, (e): $3 \% \mathrm{H}_{2} \mathrm{O}_{2}$ at $75^{\circ} \mathrm{C}$, (f): $15 \% \mathrm{H}_{2} \mathrm{O}_{2}$ at $75{ }^{\circ} \mathrm{C}$, (g): $6 \mathrm{~h}$ at $1000 \mathrm{C},(\mathrm{h}): 24 \mathrm{~h}$ at $100{ }^{\circ} \mathrm{C}$, (i): $254 \mathrm{~nm}$ for $24 \mathrm{~h},(\mathrm{j}): 360 \mathrm{~nm}$ for $24 \mathrm{~h}$.

\section{CONCLUSION}

In this study, the degradation products of ROX, TIL and TYL were analyzed by subjecting them to various stress degradation conditions recommended by $\mathrm{ICH}$. This study provides guidance for identifying instabilities of these drugs created in accordance with the recommendations of ICH guidelines. The information obtained as a result of degradation studies will help to stabilize these substances and facilitate the further study of their clinical applications.

\section{References}

1. Rensen B.H. Algal toxicity of antibacterial agents used in intensive farming. Chemosphere 40 (2000) 731-739.

2. Ying GG, He LY, Ying AJ, Zhang QQ, Liu YS, Zhao JL. China must reduce its antibiotic use. Environmental Science \& Technology 51 (2017) 1072-1073.

3. Chun-Xiang L, Han J, Wang Y, Yong-Sheng Y, Xiao-Hui X, JianMing P, Analytica Chimica Acta 653 (2009) 178-183.

4. Zhang H, Lu Y, Zhang G, Gao S, Sun D, Zhong Y. Bupivacaineloaded biodegradable poly(lactic-co-glycolic) acid microspheres I. Optimization of the drug incorporation into the polymer matrix and modelling of drug release. International Journal of Pharmaceutics 351 (2008) 244-249.

5. Yang Y, Yuan L, Li J, Muhammad I, Cheng P, Xiao T, Zhang X. Preparation and evaluation of tilmicosin microspheres and lungtargeting studies in rabbits. The Veterinary Journal 246 (2019) 27-34.

6. Cheng J, Ye Q, Yang Z, Yang W, Zhou J, Cen K. Chlorella PYZU1 during tilmicosin removal from wastewater under 15\% CO2. Journal of Hazardous Materials 324 (2017) 414-419.

7. Paesen J, Cypers W, Busson R, Roets E, Hoogmartens J. Isolation of decomposition products of tylosin using liquid chromatography, Journal of Chromatography A 699 (1995) 99-106.

8. Daugherty AL, Mrsny RJ. Formulation and delivery issues for monoclonal antibody therapeutics, Advanced Drug Delivery Reviews 58 (2006) 686-706.

9. Filipe V, Hawe A, Carpenter JF, Jiskoot W. Analytical approaches to assess the degradation of therapeutic proteins, Trac-Trends in Analytical Chemistry 49 (2013) 118-125.

10. Tamizi E, Jouyban A. Forced degradation studies of biopharmaceuticals: Selection of stress conditions. European Journal of Pharmaceutics and Biopharmaceutics 98 (2016) 26-46.

11. Wahba MEK. Liquid chromatographic determination of roxithromycin: application to stability studies. Journal of Chromatographic Science 51 (2013) 44-52.

12. Prats C, Francesch R, Arboix M, Pérez B. Determination of tylosin residues in different animal tissues by high performance liquid chromatography. Journal of Chromatography B 766 (2001) 57-65.

13. Zhang Y, Pan Z, Ronga C, Shao Y, Wang Y, Yu K. Transformation of antibacterial agent roxithromycin in sodium hypochlorite disinfection process of different water matrices. Separation and Purification Technology 212 (2019) 528-535.

14. Şanli S, Palabiyik IM, Şanli N, Guzel-Seydim SB, Alsancak G. Optimization of the experimental conditions for macrolide antibiotics in high performance liquid chromatography by using response surface methodology and determination of tylosin in milk samples. Journal of Analytical Chemistry 66 (2011) 838-847.

15. ICH, Stability Testing of New Drug Substances and Products (Q1AR): International Conference on Harmonization, IFPMA, Geneva, 2000. 